\title{
DESEMPENHO DE DIFERENTES ESTÁDIOS EMBRIONÁRIOS NO CULTIVO in vitro DE EMBRIÕES DE 'PÊRA RIO' $x$ 'PONCÃ'1
}

\author{
EDVAN ALVES CHAGAS ${ }^{2}$, MOACIR PASQUAL $^{3}$, LEONARDO FERREIRA DUTRA ${ }^{3}$, ADRIANO BORTOLOTTI DA \\ SILVA $^{3,4}$, JAIRO OSVALDO CAZETTA ${ }^{2}$, FLÁVIA CARVALHO SANTOS ${ }^{3}$, POLLYANA CARDOSO ${ }^{3}$
}

\begin{abstract}
RESUMO - Objetivou-se verificar qual o melhor estádio embrionário para o cultivo de embriões imaturos oriundos de frutos provenientes de hibridação entre 'Pêra Rio'x 'Poncã', bem como o efeito de diferentes concentrações do meio de cultura MT. Os embriões em diferentes estádios de desenvolvimento (globulares, torpedo e cordiforme) foram excisados e inoculados em tubos de ensaio contendo $15 \mathrm{~mL}$ do meio MT com diferentes concentrações $(0 ; 50 ; 100$ e 150\% da composição original e acrescido de 50 g.L.-1 de sacarose). Após a inoculação, os embriões foram incubados à $27 \pm 1^{\circ} \mathrm{C}$, fotoperíodo de 16 horas e irradiância de $32 \mu \mathrm{mol} \cdot \mathrm{m}^{-2} \cdot \mathrm{s}^{-1}$. Após 90 dias, avaliou-se o comprimento da parte aérea e do sistema radicular, massa fresca e número de folhas das plântulas. Melhor desenvolvimento dos embriões imaturos foi obtido em estádio cotiledonar e com a concentração de $150 \%$ do meio MT.
\end{abstract}

Termos para indexação: Citrus sinensis, Citrus reticulata, meio de cultura, cultura de embriões

\section{PERFOMANCE OF DIFFERENT EMBRYO STAGE OF SWEET ORANGE $x$ MANDARIN CULTIVATED in vitro}

ABSTRACT - Embryos obtained from Citrus sinensis Osbeck 'Pêra Rio' x Citrus reticulata Blanco 'Poncã' crossings were excised in diverse phases of development and cultivated in different medium concentrations. Embryos in globular, torped and cotiledonary stage were excised and inoculated individually in test tubes with $15 \mathrm{~mL}$ in distinct MT medium concentrations $(0 ; 50 ; 100$ and $150 \%$ of original composition and added sucrose (50 g.L). After inoculation, the embryos were maintained in growth room at $27 \pm 1^{\circ} \mathrm{C}, 16$ hour photoperiod and 32 umol.m ${ }^{-2} . \mathrm{s}^{-1}$ irradiance. After 90 days, the length of the aerial part and roots system, fresh mass and number of leaves, were evaluated. The best results were obtained by incubating embryos in the cotiledonary stage, in MT medium with concentrations of $150 \%$.

Index terms: Citrus sinensis, Citrus reticulata, culture medium, embryos culture

Os métodos clássicos de melhoramento, utilizados na obtenção de novos híbridos em Citrus e gêneros afins, estão limitados por problemas como apomixia, elevadas taxas de heterozigose, incompatibilidade sexual, esterilidade masculina e feminina, além de longo período de juvenilidade (Cameron \& Frost, 1968; Soost \& Cameron, 1975). A elevada taxa de poliembrionia, generalizada entre as espécies de Citrus, resulta normalmente em elevada taxa de aborto do embrião zigótico, devido à competição exercida sobre ele pelos embriões nucelares, geralmente mais vigorosos (Soost \& Cameron, 1975). Entretanto, esses embriões podem ser resgatados via cultivo in vitro em meio de cultura adequado (Sharma et al., 1996).

O sucesso no resgate de embriões híbridos dependerá, principalmente, do estádio em que o embrião está sendo excisado e da composição do meio de cultura utilizado no cultivo in vitro. De maneira geral, o embrião, durante o seu desenvolvimento, passa pelas fases globular, cordiforme, torpedo e cotiledonar, sendo que o cumprimento destas fases é imprescindível para a perfeita formação da plântula. Ocorre, porém, que embriões em estádios de desenvolvimento globular e cordiforme são mais exigentes em relação ao meio de cultivo, pois quanto mais jovens os embriões, mais difícil é o cultivo in vitro, devido ao seu pequeno tamanho e danos durante a excisão e, mais complexas são suas exigências nutricionais (Hu \& Ferreira, 1998).

Diversos meios de cultura ou suas modificações têm sido utilizados no cultivo in vitro de embriões em diferentes estádios de desenvolvimento embrionário de acordo com o gênero, espécie ou variedades. Entretanto, definir o meio de cultura e/ou sua composição, com possibilidade de sustentar o crescimento e desenvolvimento de embriões imaturos, se constitui no aspecto mais importante da cultura de embriões in vitro (Pasqual et al., 2001). Em razão disso, têm sido realizados inúmeros trabalhos com o objetivo de elucidar os efeitos de diversos fatores no cultivo in vitro de embriões de citros, dentre eles a concentração ótima de macro e micronutrientes, vitaminas e misturas complexas do meio de cultura MT (Morais, 1997), além de estudos de iden- tificação dos estádios de desenvolvimento embrionário (Ribeiro et al., 1999).

Desta forma, objetivou-se estudar o cultivo de embriões imaturos em diversos estádios embrionários oriundos de frutos provenientes da hibridação entre laranjeira 'Pêra Rio' x tangerineira 'Poncã', bem como o comportamento destes em diferentes concentrações do meio MT.

Utilizaram-se frutos com 3 a $4 \mathrm{~cm}$ de diâmetro, provenientes de hibridações entre Citrus sinensis Osbeck 'Pêra Rio' x Citrus reticulata Blanco 'Poncã'. As sementes foram removidas e tratadas com álcool $70 \%$ por cinco minutos e, posteriormente, com hipoclorito de sódio $2 \%$, por 20 minutos, sendo em seguida lavadas três vezes com água destilada e autoclavada. Em condições assépticas, os embriões no estádio globular, torpedo e cotiledonar foram excisados e inoculados individualmente em tubos de ensaio ( $25 \times 150 \mathrm{~mm})$, contendo $15 \mathrm{~mL}$ de meio de cultura MT (Murashige e Tucker, 1969), modificado com diferentes concentrações de sais e vitaminas do próprio meio $(0 ; 50 ; 100$ e $150 \%)$, acrescido de 50 g.L. - $^{-1}$ de sacarose. Após a inoculação, os embriões foram incubados em sala de crescimento a $27 \pm 1^{\circ} \mathrm{C}$, fotoperíodo de 16 horas e irradiância de $32 \mu \mathrm{mol} \cdot \mathrm{m}^{-2} \cdot \mathrm{s}^{1}$. O delineamento experimental foi inteiramente casualizado, com 4 repetições, sendo cada repetição constituída por três tubos, em esquema fatorial 3 x 4 . Após 90 dias, as plântulas foram avaliadas com base no comprimento da parte aérea e do sistema radicular, massa fresca e número de folhas.

O maior comprimento da parte aérea $(1,63 \mathrm{~cm})$ foi obtido com embriões no estádio cotiledonar, seguido por aqueles no estádio torpedo, independentemente da concentração do meio de cultura utilizado (Tabela 1). O comprimento da parte aérea aumentou linearmente com o incremento das concentrações do meio de cultura MT para todos os estádios (Figura 1A). Embora a concentração de sais do meio MT seja alta, o que poderia causar toxidez aos embriões, provavelmente a alta concentração de sacarose $\left(50\right.$ g. $\left.\mathrm{L}^{-1}\right)$ atua como um atenuador do meio, evitando danos aos embriões. Hu \& Ferreira (1998) citam que os

\footnotetext{
${ }^{1}$ (Trabalho 066/2003). Recebido: 10/06/2003. Aceito para publicação: 01/10/2003. Parte da dissertação apresentada a Universidade Federal de Lavras (UFLA) para obtenção do título de mestre.

2 FCAV/UNESP - Departamento de Tecnologia, Rod. Prof. Paulo Donato Castellane, s/n, 14884-900. Jaboticabal, SP. E-mail: cazetta@fcav.unesp.br, edyvanchagas@bol.com.br.

${ }^{3}$ Departamento de Agricultura, Universidade Federal de Lavras (UFLA). Cx. Postal, 37, 37200-000. Lavras, MG. E-mail: mpasqual@ufla.br

${ }^{4}$ Bolsista BAT/FAPEMIG.
} 
TABELA 1 - Comprimento da parte aérea (CPA) de plântulas oriundas de embriões imaturos em diferentes estádios embrionários provenientes do cruzamento controlado entre laranjeira 'Pêra Rio' x tangerineira 'Poncã' quando cultivados em diferentes concentrações do meio MT. UFLA, Lavras, MG, 2002.

\begin{tabular}{lc}
\hline \multicolumn{1}{c}{ Estádios de desenvolvimento } & CPA (cm) \\
\hline Globular & $0,97 \mathrm{c}$ \\
Torpedo & $1,22 \mathrm{~b}$ \\
Cotiledonar & $1,63 \mathrm{a}$ \\
\hline
\end{tabular}

Médias seguidas por letras distintas diferem entre si a $1 \%$ de probabilidade, segundo o teste de Tukey.

carboidratos desempenham importante papel na manutenção da osmolaridade adequada do meio de cultura. Os mesmos autores ainda descrevem que quanto mais jovem for o embrião, mais alta deverá ser a osmolaridade do meio.

O comprimento do sistema radicular, massa fresca e número de folhas por plântula aumentou linearmente com o incremento das concentrações do meio MT para os embriões nos estádios globular, torpedo e cotiledonar. Os maiores valores para as variáveis analisadas foram obtidos com embriões no estádio cotiledonar, seguidos por aqueles no estádio torpedo e globular (Figuras 1B, 1C e 1D).

De maneira geral, o maior desenvolvimento de embriões foi obtido no estádio cotiledonar, seguido pelo estádio torpedo. Independentemente do estádio em que foram excisados, houve desenvolvimento significativo dos embriões com o incremento das concentrações do meio de cultura MT (Figuras 1A, 1B, 1C e 1D). Esse maior potencial de desenvolvimento dos embriões nos estádios cotiledonar e torpedo, juntamente com a disponibilidade de nutrientes do meio de cultura, provavelmente induziu o maior desenvolvimento destes tipos de embriões no presente trabalho.
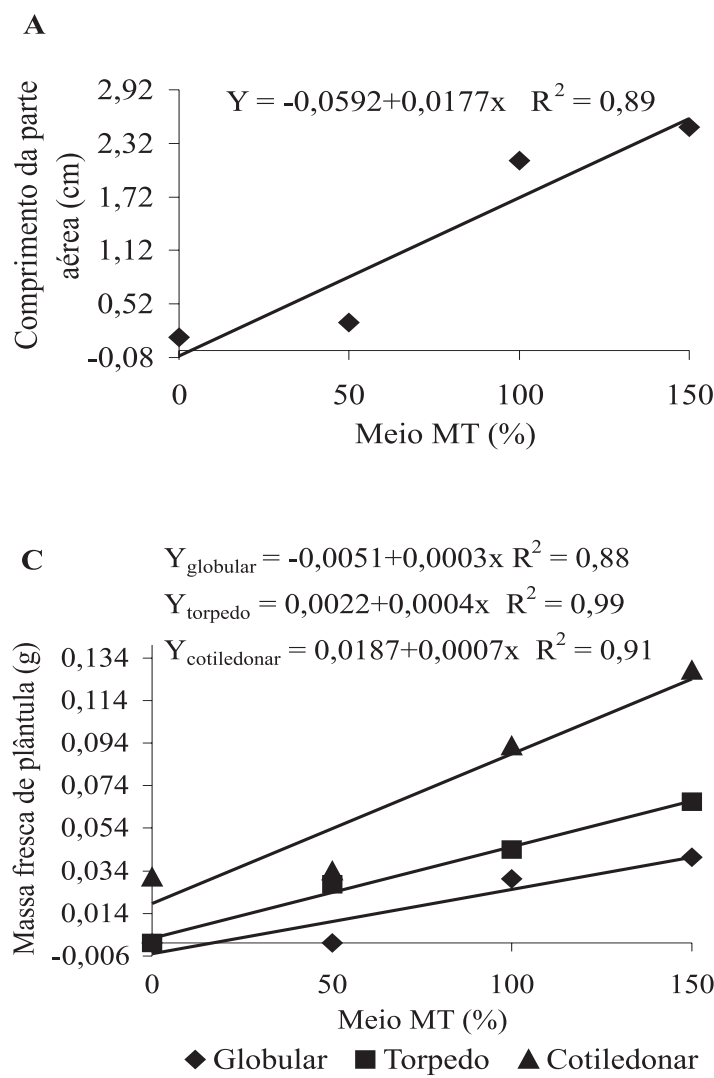

FIGURA 1 - Comprimento da parte aérea (A) e do sistema radicular (B), massa fresca (C) e número de folhas (D) de plântulas oriundas de embriões em diferentes estádios embrionários provenientes de hibridação entre laranjeira 'Pêra Rio' x tangerineira 'Poncã', cultivados em diferentes concentrações do meio MT. UFLA, Lavras, MG, 2002.

Carimi et al. (1998) verificaram que a germinação dos embriões de citros foi máxima naqueles que se encontravam no estádio cotiledonar. Em contrapartida, aqueles no estádio globular tiveram baixa germinação e desenvolvimento lento. Quando os embriões estão em fases mais desenvolvidas adquirem uma capacidade autotrófica e, por vezes, podem responder melhor às condições do meio de cultura (Rhagavan, 1976 \& 1980). Devido ao fato de apresentarem maior tamanho ( $\geq 5 \mathrm{~mm})$, estes embriões germinam mais facilmente provavelmente pela maior quantidade de reservas nutritivas presente em seus cotilédones. Ribeiro et al. (1999), trabalhando com estádios de desenvolvimento embrionário e localização do embrião zigótico em sementes de citros, também observaram que embriões zigóticos que alcançaram o pleno desenvolvimento encontravam-se no estádio cotiledonar, caracterizando menor dependência de suprimentos exógenos para germinar e desenvolver.

Os embriões no estádio globular tenderam a apresentar menor desenvolvimento, resultados estes que concordam com o afirmado por Bruck \& Walker (1985) ao mencionarem que o cultivo de embriões é dependente do genótipo e estádio de desenvolvimento, sendo a taxa de germinação inversamente proporcional à idade do embrião. Rhagavan (1976 \& 1980) descreve que embriões em fase inicial de desenvolvimento são heterotróficos e, muitas vezes, as condições ideais de nutrição são desconhecidas. Entretanto, é interessante que se estude as condições que viabilizem o cultivo de embriões globulares, pois, devido à depressão endogâmica, bastante comum no gênero Citrus, quanto mais cedo resgatá-los, maior a possibilidade de sobrevivência e melhor desenvolvimento dos embriões zigóticos que são os mais importantes nos programas de melhoramento.

O melhor desenvolvimento de embriões imaturos dos cruzamentos 'Pêra Rio' x 'Poncã' é obtido quando os mesmos são excisados no estádio cotiledonar e incubados na concentração de $150 \%$ do meio de cultura MT.

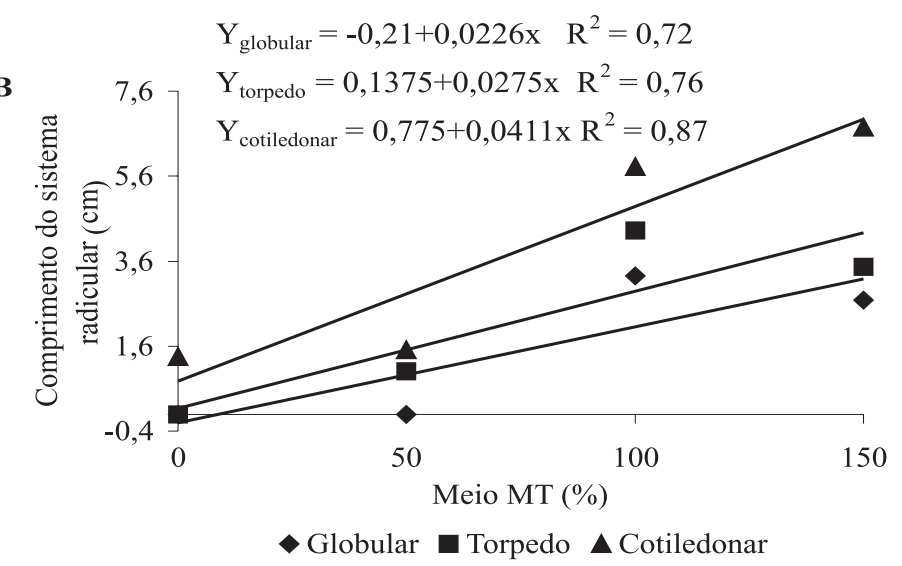

D

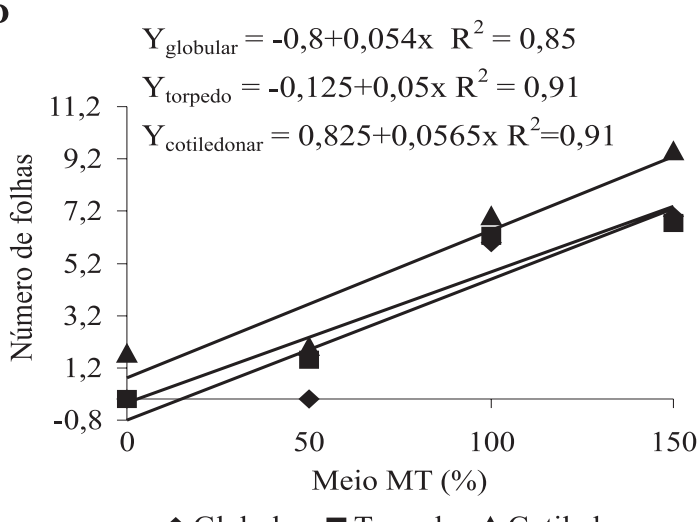

150

Globular 


\section{REFERÊNCIAS BIBLIOGRÁFICAS}

BRUCK, D.K.; WALKER, D.B. Cell determination during embryogenesis in Citrus jambhiri. I. Ontogeny of the epidermis. Botanical Gazette, Chicago, v.146, n.2, p.188-195, 1985.

CAMERON, J.W.; FROST, H.B. Genetics, breeding, and nucellar embryony. In: REUTHER, W., BATCHELOR, L.D.; WEBBER, H.J. Ed. Citrus Industry, Bartow, v.2, p.325-370, 1968.

CARIMI, F.; PASQUALE, F. de; PUGLIA, A.M. In vitro rescue of zigotic embryos of sour orange, Citrus aurantium L., and their detection based on RFLPanalisys. Plant Breeding, Berlin, v.117, n.3, p.261266, 1998.

HU, C.Y.; FERREIRA, A.G Cultura de embriões. In: TORRES, A.C.; CALDAS, L.S.; BUSO, J.A. (Ed.) Cultura de tecidos e transformação genética de plantas. Brasília: EMBRAPA/CNPH/CBAB, 1998. v.2, p.371-393.

MORAIS, L.S. Ajuste do meio de Murashige e Tucker (MT) para o cultivo in vitro de embriões imaturos de tangerina "Cleópatra" 1997. 86f. Dissertação (Mestrado em Fitotecnia)-Universidade Federal da Bahia, Cruz das Almas, BA., 1997.

MURASHIGE, T.; TUCKER, D.P.H. Growth factor requirement of citrus tissue culture. In: INTERNACIONAL CITRUS SYMPOSIUM, 1. 1969, Riverside. Proceedings... Riverside: University of California, 1969. v.3, p.1155-1169.

PASQUAL, M.; RAMOS, J.D.; DUTRA, L.F. Aplicações no melhoramento genético de plantas. 2001. 79p. Curso de Pós-Graduação "Lato Sensu" (Especialização em Cultura de Tecidos Vegetais: tecnologia e aplicações)-Universidsade Federal de Lavras, Lavras.

RAGHAVAN, V. Experimental embryogenesis in vascular plants. London: Academic, 1976.

RAGHAVAN, V. Embryo culture. Internantional Revision Cytology, n.11, p.209-240, 1980.

RIBEIRO, V.G.; PASQUAL, M.; RAMOS, J.D.; BEARZOTI, E.; NETO, S.D. Estádios de desenvolvimento embrionário e localização do embrião zigótico em sementes de citros. Pesquisa Agropecuária Brasileira, Brasília, v.34, p.1327-1333, 1999.

SHARMA, D.R.; KAUR, R.; KUMAR, K. Embryo rescue in plants - a review. Euphytica, Dorchecht, v.89, p.325-337, 1996.

SOOST, R.K.; CAMERON, J.W. Citrus. In: JANICK, J.; MOORE, J.N. (Ed.). Advances in fruit breeding. West Lafayette, Indiana: Purdue University, 1975. p.507-540. 